\title{
The Impact of Brand Image, Brand Trust towards Brand Loyalty of Indosat Telecommunication Operator Customer in Bandung
}

\author{
T. Djatmiko \\ Universitas Pendidikan Indonesia \\ Bandung Indonesia \\ tjah08no@gmail.com
}

\author{
A. Novianto \\ Telkom University \\ Bandung Indonesia \\ Aldynovianto@gmail.com
}

\begin{abstract}
The growth of telecommunications service subscribers in Indonesia until 2015 is approaching saturation and will make more tough competition. This study analyzes the effect of brand trust and the brand image toward brand loyalty of the telecommunication service customers of a company. This study tried to determine the effect of variables brand image and brand trust towards brand loyalty from telecommunication customer of PT Indosat. The descriptive quantitative research methods were implemented by involving two independent variables Brand Image (X1), and Brand Trust (X2) and one dependent variable Brand Loyalty (Y). A nonprobability purposive sampling is used as a sampling technique. The result of multiple linear regression analysis showed that the brand trust is the most influencing variable towards the brand loyalty. It means Indosat should maintain the brand trust for keeping the loyalty. Referring to the condition in which the variable brand image and brand trust resulting coefficient of determination of $68,5 \%$, the researcher suggest to the further research to add the other factor in such a way that those factors are expected will increase the value of $R$ square.
\end{abstract}

Keywords-Brand Image, Brand Loyalty, Brand Trust, Indosat

\section{INTRODUCTION}

Competitive conditions among mobile telecommunications services provider that tightly increasing make all service provider companies should be able to maximize their resources effectively and efficiently. One effort that can be done is to create and perform a good image of the company to influence consumers' views about their products, through brand image
Competition among the providers to obtain and maintain their customers are no longer limited to the technical and functional issues of a product, but also by using a brand that is able to provide special image for the user. Brand image may facilitate its customers to define a product, and then by using its brand image they may choose the product

An established brand that has become a symbol of a success product may be used for influencing a customer loyalty. The development of cellular telecommunications services industry in Indonesia for the last four years in terms of revenue and numbers of customers can be described as follows:

TABLE I.

THE GROWTH OF REVENUE AND CUSTOMERS FROM CELLULER TELECOMMUNICATION INDUSTRY IN INDONESIA

\begin{tabular}{|l|l|l|l|l|}
\hline & Year 2011 & Year 2012 & Year 2013 & Year 2014 \\
\hline Revenue (Rp. Triliun) & 92.88 & 102.84 & 110.12 & 118.65 \\
\hline $\begin{array}{l}\text { Growth (from the } \\
\text { previous year) }\end{array}$ & & $11 \%$ & $7 \%$ & $8 \%$ \\
\hline $\begin{array}{l}\text { Number of Customer } \\
\text { (Millon Customers) }\end{array}$ & $\mathbf{2 2 2 . 8}$ & $\mathbf{2 5 2 . 0}$ & $\mathbf{2 7 3 . 0}$ & 275.2 \\
\hline $\begin{array}{l}\text { Growth (from the } \\
\text { previous year) }\end{array}$ & $113 \%$ & $8 \%$ & $1 \%$ \\
\hline
\end{tabular}

Referring to the annual report from the cellular telecommunication companies especially from Telkomsel (Telkomsel, 2014), Indosat (Indosat, 2014) and XL Axiata (XL Axiata, 2014) as shown in table 1.1 above, it can be described that the revenue of mobile telecommunications services industry is still growing and become declining in the last two years. Other things that can be understood is that the 
growth of customers is declining. This is understandable because the population in Indonesia according to the BPS (Badan Pusat Statistik, 2015) is 254 million. The number of subscribers and revenue from Indosat during the last four years can be explained as follows [1]:

TABLE II.

THE GROWTH OF REVENUE AND CUSTOMERS FROM PT INDOSAT

\begin{tabular}{|l|l|l|l|l|}
\hline & Year 2011 & Year 2012 & Year 2013 & Year 2014 \\
\hline Revenue (Rp. Triliun) & 21.5 & 22.4 & 23.9 & 24.1 \\
\hline $\begin{array}{l}\text { Growth (from the } \\
\text { previous year) }\end{array}$ & & $4 \%$ & $7 \%$ & $8 \%$ \\
\hline $\begin{array}{l}\text { Number of Customer } \\
\text { MillonCustomers) }\end{array}$ & 47.2 & 58.5 & 57.6 & 54.3 \\
\hline $\begin{array}{l}\text { Growth (from the } \\
\text { previous year) }\end{array}$ & & $24 \%$ & $-2 \%$ & $-6 \%$ \\
\hline $\begin{array}{l}\text { Growth from the } \\
\text { previous year) }\end{array}$ & & $24 \%$ & $-2 \%$ & $-6 \%$ \\
\hline
\end{tabular}

Referring to the table 1.2 it can be understood that PT Indosat Tbk has a revenue growth over the past four years, however, the number of customers has decreased over the last two years. It can be understood that there is a loyalty declining from the customer of PT Indosat Tbk. Because of the growth of mobile telecommunication services industry is in saturation condition, it can be understood that the unloyal customer of PT Indosat moved to the competitors.

Referring to the above mentioned conditions, it is necessary to study further concerning the cause of the unloyal customers of Indosat. The causes that are predicted are the issue of image and brand trust. Another thing to be considered by the author is the results of a survey The information is issued in 2013, means that the data has been obtained in 2012 in which at that time the Indosat customers increased Referring to the description above, the research objectives will be carried out is as follows [2]:

\section{RESEARCHPURPOSES :}

"Knowing the influence of brand image and brand trust on brand loyalty of Indosat's customers"

\section{LITERATURE REVIEW}

\section{A. Consumer Behavior}

"The dynamic interaction of affect and cognition, behavior and the environment by which human beings conduct and exchange aspects of their lives [3]"

\section{B. Brand}

"Name, term, sign, symbol, or design, or a combination of them, intended to identify the goods and services of one seller or group of sellers and to differentiate them from those of competition [3]"

From this definition it can be understood that the brand is something that can be the name, symbols, signs, designs, or any combination thereof which has the objective to identify and distinguish between a company's products with products of other companies, in addition to communicating the product to consumers

"A brand is therefore more than a product, Because It can have dimensions that differentiate it in some way from other products designed to satisfy the same need. Reviews These differences may be rational and tangible-related to product performance of the brand - or more symbolic, emotional, and intangible related to what the brand represents"

From the above statement it can be understood that the brand is something that can exceed the product because it can be something that is either tangible or intangible form that can be expressed as symbols and emotions. [3]

\section{A. Brand image}

"Once a sufficient level of brand awareness is created, marketers can put more emphasis on crafting a brand image"

"Creating brand awareness by increasing a familiarity of the brand through repeated exposure (for brand recognition) and forging strong associations with the appropriate product categoryor other relevant purchase or consumption cues (for brand recall) is an important first step in building brand equity"

From the two statements mentioned above, it can be understood that the brand image is something more valuable than the product. Another thing that can be understood is the brand can be used as a difference of a product with another similar product, especially by using the brand image [3].

\section{1) Attributes}

The characteristics of the various aspects of brand that are promoted. Attributes can consist of things that are not related to the product (eg: price, packaging, consumer, and image usage), and matters relating to the product (eg color, size, design).

\section{2) Benefits}

The benefits of these products, namely the functional benefit, symbolic, and experience.

3) Overall Evaluation 
The value or subjective interests of the customers towards these products.

\section{B. Brand Trust}

"Feeling of security held by the consumer in his/her interaction with the brand, that it is based on the perceptions that the brand is reliable and responsible for the interests and welfare of the consumer"

From the definition it can be understood that brand trust is based on customer perceptions. Furthermore, brand trust can be measured in two dimensions, namely [4],

\section{1) Dimension of Viability}

A perception which states that a brand can meet and satisfy the needs and values of consumers.

2) Dimension of intentionality

A reflection of an individual's feeling of security to a brand that is measured through indicators of security and trust.

"In general, trust involves two exchange partners. In the context of our research, the two exchange partners are the user of the mobile phone and the mobile phone company. Brand trust is based on the perception that the company represented by the brand is reliable and responsible for the interest and welfare of the user" [4].

\section{Brand Loyalty}

According to the American Marketing Association. Brand loyalty is defined as

"Brand loyalty is where a person buys products from the same manufacturer repeatedly rather than from other suppliers"

"...the enhanced relationships in the customer centric model of brand community should increase brand trust, which has a positive effect on brand loyalty, i.e., brand trust has a mediating role in translating the effects of brand community into brand loyalty"

It is also mentioned by that they buy more and regularly and frequently recommend as well as advice about a brand to others [5].

From this understanding, it is understood that a loyal customer is a customer who does not buy similar products from other manufacturers. The other unders tanding is that brand trust also become an important thing for influencing the brand loyalty. Furthermore, to measure customer loyalty, according it is necessary to make measurements of brand loyalty, as follows [6]:

\section{1) Behavior Measures}

It is measure by knowing the patterns of regular purchases made by consumers. Measurements were made of the level of repeat purchases (purchase rate), the percentage of the purchase, and the number of brands purchased.

2) Measuring Switching

Cost Carried out by analyzing the cost of sacrifice to switch brands

3) Measuring Satisfaction

Measurement to measure the level of satisfaction or customer dissatisfaction. It is an important tool for detecting the level of customer loyalty.

4) Measuring Liking Brand

A customer should involve. A comprehensive customer can be measured through various ways

5) Measuring Commitment

Performed by measuring customer commitment. One important indicator of commitment is about the amount of interaction and communication involved in a product.

\section{RESEARCHFRAMEWORK}

The framework of the research by using brand image and brand trust as the attributes to understand the effect of those variables to brand loyalty are as follows

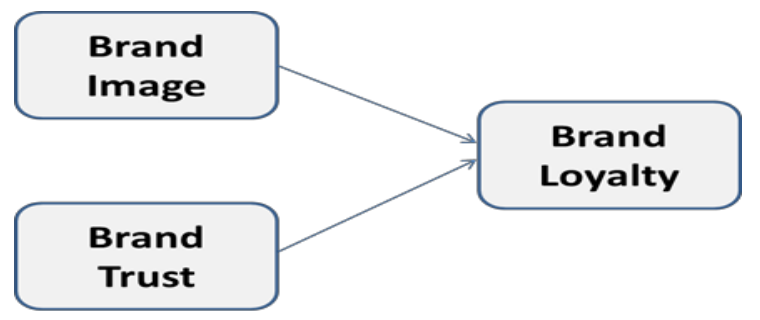

Fig. 1. Research Framework

\section{RESEARCH METHODOLOGY}

\section{A. Research design}

The descriptive quantitative research methods was implemented. the descriptive analysis is the elementary transformation data in a way that describes the basic characteristic such as distribution and variability. The sampling method is a purposive sampling. The sampling technique is a non-probability sampling. The research is using two independent variables Brand Image (X1), and Brand Trust (X2) and one dependent variable Brand Loyalty (Y). 


\section{B. Data collection Process}

The data were gathered by using questioner come from 100 respondents. The respondents are located in south part of Bandung

\section{Data Analysis}

The data were analyzed by using multi linear regression and processed by SPSS 20

\section{Operational Variable}

Two attributes specified as independent variables, the brand image (X1) and the brand trust (X2). The dependent variable is Brand Loyalty (Y). The Operation Variable items are mention as in table 2.1

The scale of measurement used is a Likert scale of 5, in which the alternative answers are Strongly Disagree (1) Disagree (2), Neutral (3) Agree (4) and Strongly Agree (5).

The operational variable is done by looking the behavioral dimension's facets or properties denoted by the concept [7]. There are two independent variables and one dependent variable that are used in this research. The operational variables are shown in table 2.1

TABLE III. OPERATIONAL VARIABLE

\begin{tabular}{|c|c|c|c|}
\hline Variable & Sub Variable & Indicator & Scale \\
\hline \multirow{5}{*}{$\begin{array}{l}\text { Brand Image } \\
\text { (X1) }\end{array}$} & \multirow{2}{*}{ Attributes } & Easily recognized the logo & Ordinal \\
\hline & & $\begin{array}{l}\text { Indosat gives the classy } \\
\text { impression for its users }\end{array}$ & yrdinal \\
\hline & Benefits & $\begin{array}{llll}\begin{array}{l}\text { Indosat } \\
\text { product }\end{array} & \text { having a quality } \\
\end{array}$ & Ordinal \\
\hline & \multirow[b]{2}{*}{ Overall evaluation } & $\begin{array}{l}\text { Indosat is a provider with a } \\
\text { famous brand }\end{array}$ & ardinal \\
\hline & & $\begin{array}{l}\text { Indosat brand image makes } \\
\text { me think positively towards } \\
\text { Indosat }\end{array}$ & Ordinal \\
\hline \multirow{6}{*}{$\begin{array}{l}\text { Brand Trust } \\
\text { (X2) }\end{array}$} & \multirow{2}{*}{$\begin{array}{l}\text { Dimension } \\
\text { Viability }\end{array}$} & $\begin{array}{l}\text { Brand with high reputation } \\
\text { The Brand consistent with the } \\
\text { quality }\end{array}$ & \begin{tabular}{|l} 
Ordinal \\
erdinal
\end{tabular} \\
\hline & & $\begin{array}{l}\text { The company's attention to } \\
\text { customers }\end{array}$ & Ordinal \\
\hline & \multirow{4}{*}{$\begin{array}{l}\text { Dimension } \\
\text { Intentionality }\end{array}$} & $\begin{array}{l}\text { Do not harm customers } \\
\text { (loss of data, pulses, etc.) }\end{array}$ & Ordinal \\
\hline & & $\begin{array}{l}\text { Priority choice of } \\
\text { telecommunications provider } \\
\text { brand }\end{array}$ & Ordinal \\
\hline & & $\begin{array}{l}\text { Different with other } \\
\text { telecommunications providers }\end{array}$ & Ordinal \\
\hline & & $\begin{array}{l}\text { Security of customer data } \\
\text { can be maintained }\end{array}$ & Ordinal \\
\hline \multirow[t]{2}{*}{$\begin{array}{l}\text { Brand } \\
\text { Loyalty (Y) }\end{array}$} & $\begin{array}{l}\text { Behaviour } \\
\text { Measures }\end{array}$ & $\begin{array}{l}\text { Always buy Indosat's product } \\
\text { for fulfilling the } \\
\text { telecommunications needs }\end{array}$ & Ordinal \\
\hline & Measuring & The price of Indosat & Ordinal \\
\hline
\end{tabular}

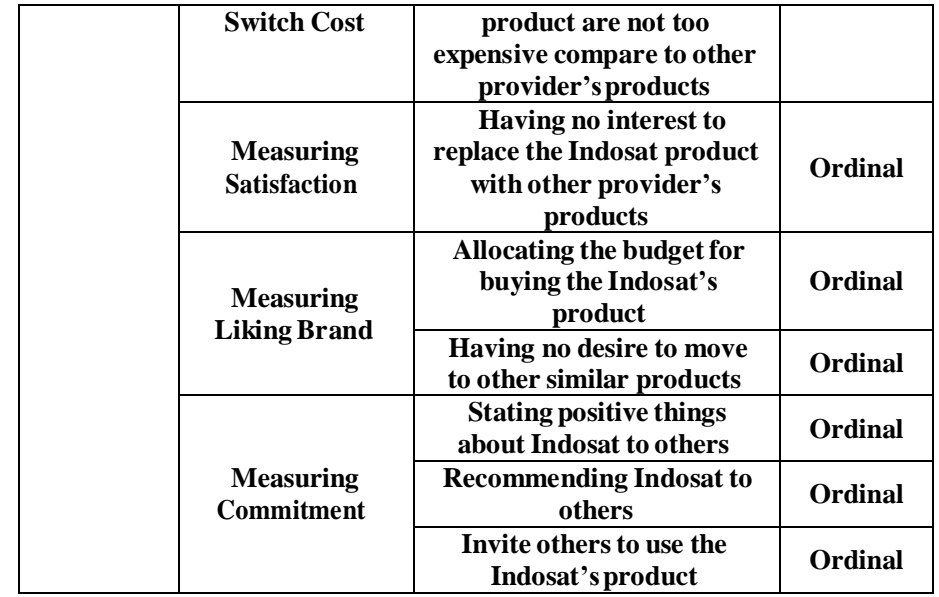

\section{RESULTS AND DISCUSSION}

\section{A. Characteristics of Respondents}

The data collected from the one hundred respondents were grouped based on several characteristics as follows:

1) Gender.

It is found that the smallest respondents are female with $40 \%$ or 40 respondents. Then the predominant number of respondents in this study are male with $60 \%$ or 60 respondents.

2) Age.

It is found that the number of respondents whose age less than 18 years old are $8 \%$ or 8 respondents, and in the range of 18-22 years old are $78 \%$ or 78 respondents, and more than 22 years old are $14 \%$ or 14 respondents. The most dominant respondents are in the range of $18-22$ years old with $78 \%$ or 78 respondents.

\section{B. Analysis the impact of brand image and brand trust towards brand loyalty}

It is necessary to test the validity and reliability of the questionnaire. validity is a test of how well an instrument that is developed mesures the particular concept it is intended to measure. Reliable is established by testing for both consistency and stability [7].

1) Validity and Reliability Test Results

In this study, the validity and reliability test are done by using SPSS ver.20. The reliability and validity of test results can be seen in Table 3.1 and table 3.2:

TABLE IV. VALIDITY TEST RESULT

\begin{tabular}{|c|c|c|c|}
\hline Variable & $\begin{array}{c}\text { Pearson } \\
\text { Correlation }\end{array}$ & R Table & Remarks \\
\hline Brand Image & $>0,1966$ & 0,1966 & Valid \\
\hline Brand Trust & $>0,1966$ & 0,1966 & Valid \\
\hline Brand Loyalty & $>0,1966$ & 0,1966 & Valid \\
\hline
\end{tabular}


Based on the Table 3.1 it can be shown that because of all Pearson correlation values are greater than 0.1966 (> 0.1966) we may conclude that all of the question variables are valid. It means can be used for gathering the data

TABLE V. RELIABILITY TEST RESULT

\begin{tabular}{|c|c|c|}
\hline Variable & $\begin{array}{c}\text { Cornbach } \\
\text { Alpha Result }\end{array}$ & Remarks \\
\hline Brand Image & 0.730 & Reliable \\
\hline Brand Trust & 0.845 & Reliable \\
\hline Brand Loyalty & 0.897 & Reliable \\
\hline
\end{tabular}

Based on the Table 3.2, it can be shown that the questions for brand image, brand trust and brand loyalty can be classified as reliable

\section{2) Regression Analysis}

The result of the analysis can be shown and conclude from table 3.3 as follows

TABLE VI. COEFFICIENTS

\begin{tabular}{|c|c|c|c|c|c|}
\hline \multirow{2}{*}{ Model } & \multicolumn{2}{|c|}{$\begin{array}{c}\text { Unstandardized } \\
\text { Coefficients }\end{array}$} & $\begin{array}{c}\text { Stand. } \\
\text { Coeff. }\end{array}$ & \multirow{2}{*}{ t } & Sig \\
\hline & $\mathbf{B}$ & $\begin{array}{c}\text { Std } \\
\text { Error }\end{array}$ & Beta & & \\
\hline (Constant) & -2.407 & 2.611 & & -.922 & .359 \\
\hline Brand Image & .497 &. .243 & .214 & 2.044 & .044 \\
\hline Brand Trust & 1.007 & .164 & .641 & 6.125 & .000 \\
\hline
\end{tabular}

Dependent Variable: Brand Loyalty

Based on the table above, the multiple linear regression equation are as follows:

$$
\begin{aligned}
& Y=a+b 1 X 1+b 2 X 2 \\
& Y=-2.407+0.497 X 1+1.007 X 2
\end{aligned}
$$

The equation of multiple linear regression can be explained as follows:

a) The Constant value of -2.407 means that it indicates if PT Indosat doesn't make any changes to brand image and brand trust, the brand loyalty value will decrease by $2.407 \%$.

b) The variable regression coefficient value of 0.497 combined with X1 means that if the brand image has increased 1 unit then brand loyalty value will increase to 0.497 unit, by assuming that the other independent variable values are fixed.

c) The variable regression coefficient value of 1.007 combined with X2 means that if the brand trust has increased 1 unit then brand loyalty value will increase to 1.007 unit, by assuming that the other independent variable values are fixed.

From the equation we may understand that the most influencing variable for brand loyalty of PT Indosat customer is Brand Trust

The simultaneous influence of brand image and brand trust towards the loyality can be described as follows
TABLE VII. DETERMINATIONCOEFFICIENT

\begin{tabular}{|c|c|c|c|c|c|}
\hline Model & $\mathrm{R}$ & $\begin{array}{c}\mathrm{R} \\
\text { Square }\end{array}$ & $\begin{array}{c}\text { Adjusted } \\
\text { R Square }\end{array}$ & $\begin{array}{c}\text { Std Error } \\
\text { of the } \\
\text { estimate }\end{array}$ & $\begin{array}{c}\text { Durbin- } \\
\text { Watson }\end{array}$ \\
\hline 1 & .828 & .685 & .678 & 3.29528 & 1.644 \\
\hline
\end{tabular}

Predictors:(Constant), Brand Trust, Brand Image

Dependent Variable: Brand Loyalty

Referring to the table 3.4 it can be understood that the simultaneous influence of brand trust and brand image on brand loyalty is equal to 0.685 or $68.5 \%$. This figure explains that brand trust and brand image can explain the impact to brand loyalty by $68.5 \%$. While the remaining that is equal to $31.5 \%$ is explained by other variables that are not included in this study.

\section{CONCLUSIONS AND RECOMMENDATIONS}

\section{A. Conclusion}

a. The brand loyalty of PT Indosat customer will decrease while there is no action from management concerning the brand image and brand trust

b. The most influencing variable for brand loyalty of PT Indosat customer is brand trust

\section{B. Suggestions}

Based on the results of this research there are several suggestions for the company and the other researcher as follows:

a. The company (PT Indosat) has to get the information concerning the expectation of the customer concerning the brand image and brand trust

b. The company (PT Indosat) has to do some action for increasing brand image and brand trust because without doing any action from management the customer loyalty will decrease

\section{REFERENCES}

[1] Badan Pusat Statistik. (2015). Statistika Indonesia. Jakarta: BPS

[2] Fauzi. (2014, March Thursday, 06 ). Indosat Didapuk Sebagai 'Mobile Network of the Year Indonesia 2013. Retrieved July Monday , 6, 2015, http://www.tabloidpulsa.co.id.

[3] Keller, K. ( 2012). "Marketing Management” 14th edition, , . ,New Jersey (USA): Pearson Education, Prentice Hall

[4] Delgado-Ballester, E. M.-A.-G. (2003). Development and validation of a brand trust scale. . International Journal of Market Research, 45, 1, 35 - 54.

[5] Michel Laroche, M. R.-O. (2013). To be or not to be in social media: How brand loyalty is affected by social media? International Journal of Information Management 33, 76-82

[6] Rangkuti, F. (2009). The Power Of Brands . Jakarta: PT Gramedia Pustaka Utama.

[7] Sekaran, U., \& R, B. (2010 ). Research method for business . West Sussex : John Wiley \& Son Ltd. 